
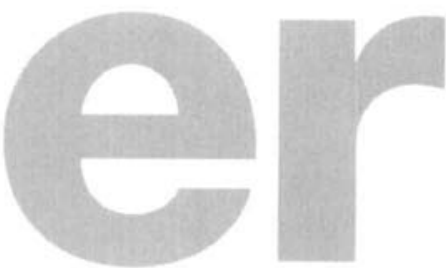

\title{
Launching the arq
}

Architectural Research Quarterly (arq) represents a stand against the new tendency to devalue and compartmentalise architectural research. We subscribe to the view, which Francis Duffy encapsulates so well ( $p$ ), that architectural knowledge is an 'integrating, value laden, holistic, design related, user responsive, inventive and entirely distinctive mode of thought'. Buildings are central to this, but theory, history, environmental and structural design, construction and information technology, management and much else contribute to the whole. We intend to publish the best available research on all these subjects.

But why should we publish at all? What is a refereed journal? And isn't a journal filled with research papers a recipe for dullness? First, we believe there is much excellent research for which there is no effective outlet. Professional journals can no longer afford to devote many pages of text to a single feature; arq can do so. Second, it has become essential for academics to publish in journals in which contributions are the subject of peer review rather than editorial decision. Every paper published in arq will have been vetted by two persons expert in the subject under review. Third, arq is pro-active. We are not just waiting for papers to drop through our letter box, we are searching them out. And, in our Issues section, we are addressing matters of contemporary importance.

In time, we hope that much of the research which we publish will be written not only by academics but also by practitioners. Outstanding student work will be welcomed. The composition of our Editorial Board, a mix of academics and practitioners, architects, engineers and others, is a reflection of our determination to include all those who have a contribution to make to the theory and practice of architecture and the quality of the built environment.

At the time of writing, arq had received nearly 120 papers and outlines since the decision was made, ten months ago, to publish. Many of the outlines have yet to blossom into papers, some of the papers have been rejected by referees and some have had to be returned as the realisable scope and focus of the journal has become apparent. But there is much excellent material emerging, more and more of it from outside the United 
Kingdom. Sadly, few practitioners seem able or even willing to write about their work; there exists an excellent opportunity for academics and younger practitioners to act as disseminators or critics of research and design in practice.

Architectural research got itself a bad name in the 1970s. Much of it had little to do with practice and still less with buildings. In the 1980s, the world of academic research was turned upside down. State funding became less common and more and more research was carried out on a commercial basis for sponsors who did not wish the results to be disseminated. And, in many countries, governments started to link academic funding with research excellence. It was, in principle, a good idea.

But today, in the 1990s, architectural research (and education) are under threat. The introduction of academic funding based on research assessment exercises has created a ludicrous situation in which academics will publish before they are ready to do so and where universities will poach staff from each other in an effort to secure a higher research rating, and hence higher funding. Much that is described as research is nothing of the kind, many academics are becoming specialists in research remote from teaching, and design is discounted as a form of research. The link between research and practice is, once more, endangered.

There are no precedents for a refereed journal covering the breadth of topics included in our pages. This will be both arq's strength and its weakness - strength in that it reflects the breadth and holistic nature of architecture, weakness in that not all those aspects are of interest to each specialist or even, let it be said, to some generalists. But write to us. Let us know what you think. Help us to shape this journal and to make it relevant, readable and controversial - a dynamic and positive contribution to the theory and practice of Architecture.

Peter Carolin 